\title{
BUDIDAYA IKAN SISTEM KERAMBA JARING APUNG GUNA MENJAGA KEBERLANJUTAN LINGKUNGAN PERAIRAN WADUK CIRATA
}

\author{
Idil Ardi \\ Pusat Penelitian dan Pengembangan Perikanan Budidaya \\ Jl. Ragunan 20, Pasar Minggu, Jakarta Selatan 12540 \\ E-mail: ardiidil@yahoo.com
}

\section{ABSTRAK}

Eksistensi budidaya ikan sistem keramba jaring apung di Waduk Cirata terus berlangsung, meskipun banyak hasil penelitian yang menyatakan bahwa lingkungan perairan waduk sudah menurun. Keberadaan budidaya ikan sistem keramba jaring apung (KJA) tetap bertahan tidak terlepas dari dukungan berbagai macam sarana produksi ikan (saprokan). Namun demikian, pada tingkat pengelolaan budidaya yang tidak terkendali tentu akan berdampak buruk bagi lingkungan perairan waduk. Penelitian bertujuan mengkaji pola budidaya sistem keramba jaring apung yang dapat meminimalisasi beban sisa pakan. Penelitian dilakukan dengan metode survai lapang dan wawancara, serta pengisian kuisioner dengan responden pembudidaya ikan sebanyak 103 orang. Hasil penelitian menunjukkan bahwa sisa pakan dari aktivitas budidaya ikan sistem KJA yang terbuang ke lingkungan perairan waduk sebesar $23 \mathrm{~kg}$ fosfor (P) per petak KJA atau sebesar 900 ton $\mathrm{P}$ per tahun. Besarnya sisa pakan yang terbuang disebabkan oleh tingkat penggunaan pakan yang tinggi (FCR 1,51\%), kandungan $P$ pakan yang tinggi dan tingkat penyerapan pakan yang rendah terutama pada ikan mas.

KATA KUNCI: budidaya, sisa pakan, lingkungan perairan waduk

\section{PENDAHULUAN}

Di Indonesia, waduk umumnya mempunyai multifungsi baik secara teknis maupun ekologis. Secara teknis waduk berfungsi sebagai pencegah banjir, penyedia air untuk pembangkit tenaga listrik, irigasi, industri, pariwisata, dan transportasi air, serta lahan pengembangan budidaya perikanan. Sementara itu, secara ekologis waduk berfungsi sebagai habitat kehidupan biota air (keanekaragaman hayati) termasuk berbagai jenis ikan endemik (Anonim, 2008).

Waduk Cirata terletak di Jawa Barat, salah satu fungsinya adalah sebagai lahan budidaya perikanan. Berdasarkan SK Gubernur Jawa Barat No. 41 tahun 2002, jumlah keramba jaring apung (KJA) di Waduk Cirata adalah 12.000 petak, yang terbagi atas tiga zona, yaitu zona 1 berada pada wilayah Kabupaten Bandung Barat sebanyak 1.896 petak KJA, zona 2 berada di Kabupaten Purwakarta sebanyak 4.644 petak, dan zona 3 di Kabupaten Cianjur sebanyak 5.460 petak.

Berkembangnya budidaya perikanan telah menjadikan perairan waduk sebagai hamparan KJA yang mendominasi luas perairan Cirata, kecuali daerah bendungan/dam, daerah perairan dangkal, dan daerah yang bergelombang besar. Banyaknya KJA telah melampaui alokasi 12.000 petak, karena yang terbangun adalah 49.985 petak (Anonim, 2008b). Teknologi budidaya ikan sistem KJA di waduk dilakukan dengan pola intensif yaitu penebaran ikan dengan kepadatan tinggi dan penggunaan pakan komersial dalam proses pembesarannya. Pola budidaya yang intensif yang tidak menjadikan daya dukung lingkungan sebagai faktor pembatasnya, umumnya berdampak terhadap menurunnya kualitas lingkungan.

Di dalam Undang-Undang Republik Indonesia Nomor 32 Tahun 2009 dijelaskan bahwa penggunaan sumberdaya alam harus selaras, serasi, dan seimbang dengan fungsi lingkungan hidup. Sebagai konsekuensinya, kebijakan, rencana, dan/atau program pembangunan harus dijiwai oleh kewajiban melakukan pelestarian lingkungan hidup dan mewujudkan tujuan pembangunan berkelanjutan. Sejauh ini, aktivitas budidaya ikan sistem KJA di waduk tetap terus berkembang untuk meningkatkan produksi. Kondisi ini 


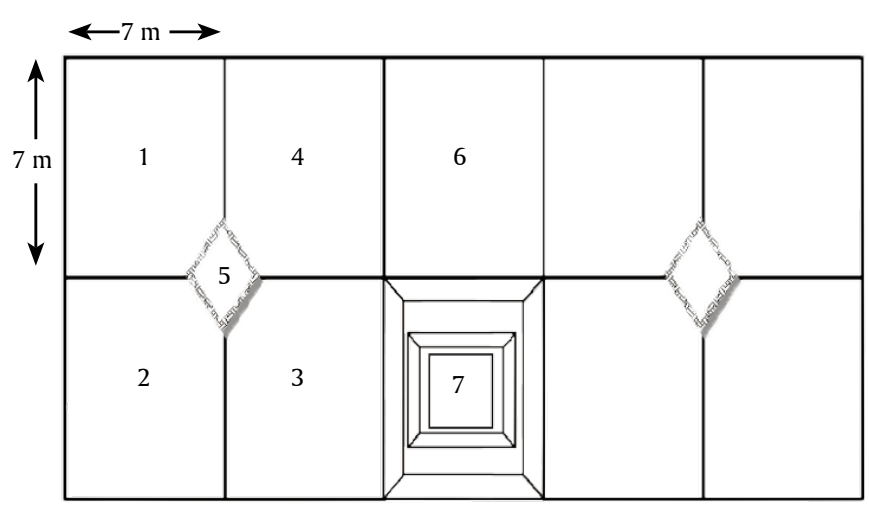

Keterangan: 1. kolam: nomor 1, 2, 3, 4 ukuran $7 \mathrm{~m}$ x 7 m masing-masing dinamakan 1 petak; 2. kolam: nomor 1, 2, 3, dan 4 empat petak dinamakan 1 unit usaha; 3. kolam: nomor 6 untuk karantina ikan; 4 . nomor 5 tempat pakan; 5 . nomor 7 rumah jaga

Gambar 1. Kolam keramba jaring apung tampak atas

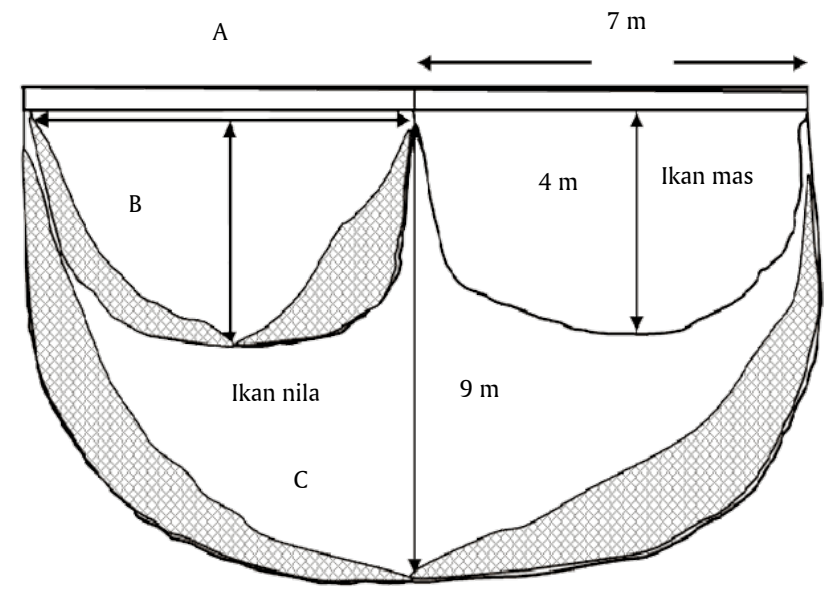

Keterangan: A. rangka; B. katong jaring lapis pertama yang diisi ikan mas atau bawal; $\mathrm{C}$. kantong jaring lapis kedua yang diisi ikan nila

Gambar 2. Kolam KJA tampak samping

tercermin dari berbagai macam saprokan (sarana produksi ikan) yang disuplai ke waduk dengan harapan agar produksi ikan dapat meningkat. Di sisi lain, belum tentu saprokan yang tersedia sesuai dan mampu diterapkan dengan baik oleh pembudidaya. Bila tidak ada kesesuaian dengan saprokan yang ada maka tidak saja merugikan pembudidaya, namun juga akan berdampak buruk bagi lingkungan perairan waduk. Oleh karenanya pengelolaan budidaya ikan sistem KJA yang berkembang di waduk perlu dikaji kembali untuk melihat kesesuaiannya. Penelitian dilakukan bertujuan mengkaji pola budidaya sistem keramba jaring apung yang dapat meminimalisasi beban sisa pakan.

\section{Teknik Budidaya Ikan Sistem KJA}

KJA ditempatkan di lokasi budidaya secara berjejer antara satu unit dengan unit KJA lainnya dan saling menyambung, tujuannya untuk mempermudah pemilik atau penjaga KJA dalam memelihara serta mengawasinya.

Budidaya ikan sistem KJA dalam operasionalnya dilengkapi dengan fasilitas pendukung yang terdiri atas rumah jaga, tempat pakan, dan kolam karantina, secara lengkap bagian-bagian KJA disajikan pada Gambar 1 . Keramba jaring apung terdiri atas keramba (jaring) dan rangka (rakit dan besi) dengan ukuran yang seragam. Satu unit KJA terdiri atas 4 petak (kolam) dan dibangun dari beberapa bagian rangka yang dilengkapi dengan dua lapis jaring. Satu petak KJA dibuat dengan ukuran panjang 7 $\mathrm{m}$, lebar $7 \mathrm{~m}$, dan dalam $4 \mathrm{~m}$. Pada setiap satu petak KJA dipasang jaring lapis pertama yang berukuran $7 \mathrm{~m} \mathrm{x} 7 \mathrm{~m} \mathrm{x}$ $4 \mathrm{~m}$. Selanjutnya dalam satu unit KJA dipasang jaring lapis kedua (jaring bawah) ukuran $14 \mathrm{~m}$ x $14 \mathrm{~m}$ x $9 \mathrm{~m}$. Bentuk susunan jaring untuk satu unit KJA ditunjukkan pada Gambar 2.

Pada Gambar 3 terlihat bahwa satu unit KJA terdiri atas empat petak dan satu rumah pakan. Jenis komoditas ikan yang dibudidayakan adalah ikan mas, nila, dan bawal. Ada dua pola budidaya yang dikembangkan yaitu pola pertama budidaya ikan mas dengan ikan nila dan pola kedua ikan bawal dengan nila.

Pola pertama budidaya ikan mas dengan nila, ikan mas ditebar dalam petak jaring lapis pertama (jaring atas) dengan jumlah penebaran dalam satu musim rata-rata $71,41 \mathrm{~kg} /$ petak. Sedangkan ikan nila ditebar dalam jaring lapis kedua (jaring bawah) dengan jumlah penebaran dalam satu musim rata-rata 69,19 kg/petak. Jumlah penebaran benih ikan mas, bawal, dan nila dalam budidaya sistem KJA disajikan pada Tabel 1. Satu musim produksi ikan mas 

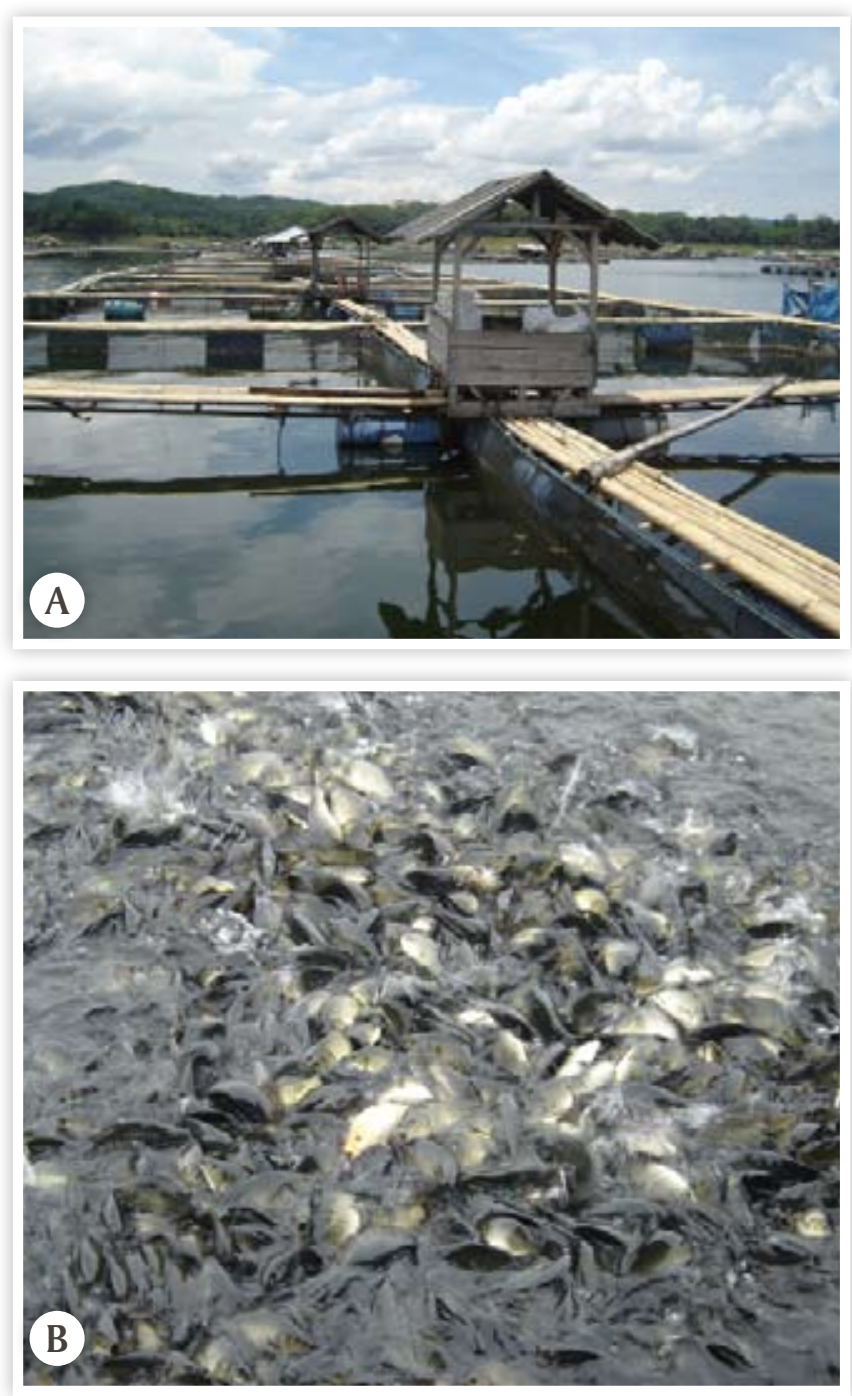

Gambar 3. Konstruksi KJA (a), ikan mas dalam satu petak KJA (b)

Tabel 1. Padat penebaran benih ikan mas, bawal dan nila per petak $\mathrm{kja}(\mathrm{kg})$ dalam satu musim produksi

\begin{tabular}{llcc}
\hline & Pola budidaya & Kisaran & Rataan \\
\hline A & Ikan mas & $30-200$ & 71,41 \\
& Ikan nila & $25-150$ & 69,19 \\
\multirow{2}{*}{ B } & Ikan bawal & $40-400$ & 122,28 \\
& Ikan nila & $30-88$ & 60,51 \\
\hline \multicolumn{3}{r}{ Rataan } \\
\hline
\end{tabular}

dipelihara selama 4 bulan, jadi budidaya ikan mas dapat dilakukan 3 musim tanam dalam setahun. Sedangkan ikan nila dalam setahun dapat dibudidayakan 2 musim, karena ikan nila dalam jaring lapis kedua pertumbuhannya lambat dan hanya mendapatkan sisa pakan dari ikan mas yang dipelihara dalam jaring lapis pertama.

Pola kedua, budidaya ikan bawal dengan ikan nila. Ikan bawal ditebar dalam jaring lapis pertama (jaring atas) dengan padat penebaran rata-rata $122,28 \mathrm{~kg}$ /petak; sedangkan dalam jaring lapis kedua ditebar ikan nila dengan padat penebaran rata-rata $60,51 \mathrm{~kg}$.

Pembesaran bawal dalam satu musim selama 2 bulan, maka dalam setahun pembesaran bawal dapat dilakukan 5 kali. Sedangkan pembesaran nila dalam satu musim tanam selama 6 bulan, jadi dalam setahun hanya 2 kali musim tanam.

Pembesaran ikan dalam KJA dengan pola pertama dan pola kedua dilakukan dengan cara intensif melalui pemberian pakan buatan (komersial) sebagai sumber makanan selama ikan dipelihara.

\section{Jenis dan Nutrisi Pakan}

Jenis pakan yang beredar di Waduk Cirata ada 11 merk pakan, namun hanya 7 merk pakan yang banyak digunakan pembudidaya yaitu pakan Pxl, Pxm, Pxn, Pxo, Pxp, Pxq, dan Pxr.

Pakan ikan yang digunakan oleh pembudidaya ikan di Waduk Cirata adalah pakan komersial dengan bermacam merk. Hasil survai ditemukan ada 11 merk pakan dengan komposisi nutrisi yang berbeda (Tabel 2).

Berdasarkan komposisi nutrisi pakan pada Tabel 2 terlihat bahwa kandungan protein relatif tidak jauh berbeda dari setiap merk pakan. Kandungan protein pakan berkisar antara 24\%-26\% dari bahan pakan. Kecuali pakan Pxs kandungan proteinnya 29\%-30\%. Ikan yang dibudidayakan secara intensif membutuhkan pakan yang berkualitas dengan nutrisi yang komplit dan seimbang. Menurut Schmittou (1991), kandungan protein pakan untuk ikan mas dan nila umumnya berkisar antara 28\%-30\%, bahkan untuk kualitas FCR pakan yang baik kandungan protein pakan $32 \%$.

Unsur nutrisi lain di dalam bahan pakan ikan yang penting adalah fosfor $(\mathrm{P})$ sehingga komposisinya di dalam 
Tabel 2. Komposisi nutrisi pakan ikan di Waduk Cirata

\begin{tabular}{lcccccc}
\hline \multirow{2}{*}{$\begin{array}{c}\text { Jenis } \\
\text { pakan }\end{array}$} & $\begin{array}{c}\text { Protein } \\
\mathbf{( \% )}\end{array}$ & $\begin{array}{c}\text { Lemak } \\
\mathbf{( \% )}\end{array}$ & $\begin{array}{c}\text { Serat } \\
\text { kasar } \\
\mathbf{( \% )}\end{array}$ & $\begin{array}{c}\text { Abu } \\
\mathbf{( \% )}\end{array}$ & $\begin{array}{c}\text { Kadar } \\
\text { air } \\
\mathbf{( \% )}\end{array}$ & $\begin{array}{c}\text { Fosfor*) } \\
(\mathbf{\%})\end{array}$ \\
\hline Pxl & 25 & 6 & 7 & 12 & 12 & 1,45 \\
Pxm & 25 & 6 & 7 & 12 & 12 & 1,64 \\
Pxn & 26 & 5 & 7 & 12 & 12 & 1,66 \\
Pxo & $24-26$ & $6-8$ & $4-6$ & $10-13$ & $11-13$ & 1,59 \\
Pxp & 24 & 5 & 7 & 12 & 12 & 1,44 \\
Pxq & 25 & 5 & 7 & 12 & 12 & 1,59 \\
Pxr & 26 & 5 & 7 & 12 & 12 & 1,50 \\
Pxs & $29-30$ & 5 & 7 & 12 & - & 1,62 \\
Pxt & 26 & 6 & 6 & 11 & 12 & 1,38 \\
Pxu & $24-26$ & $5-7$ & $6-8$ & $5-8$ & $11-13$ & 1,27 \\
Pxv & 25 & 5 & 6 & 12 & 12 & 1,40 \\
\hline Kisaran & $24-30$ & $5-8$ & $5-8$ & $5-13$ & $11-13$ & $1,27-1,66$ \\
Rataan & 25,25 & 5,33 & 6,78 & 11,89 & 12,00 & 1,50 \\
\hline Sumber: & Hasil survai data dari label pakan di Waduk Cirata tahun \\
& $2010 ;{ }^{*}$ Analisis laboratorium & &
\end{tabular}

bahan pakan harus sesuai dengan standarnya. Sebagian besar pakan yang digunakan di Waduk Cirata tidak diketahui jumlah komposisi P yang terdapat di dalam bahan pakan karena komposisi $\mathrm{P}$ pakan tidak diinformasikan seperti kandungan nutrisi pakan lainnya pada label pakan.

Fosfor di dalam bahan pakan dibutuhkan sebanyak 0,5\%-0,9\% yang berfungsi untuk pertumbuhan, pembentukan tulang, dan membantu metabolisme lemak dan karbohidrat (Watanabe, 1988). Hasil analisis jumlah P dalam sejumlah bahan pakan yang terdapat di Waduk Cirata sangat bervariasi dengan kisaran antara 1,22\%1,66\% (Tabel 2). Dari tabel tersebut diketahui bahwa $P$ pakan rata-rata $1,5 \%$. $\mathrm{P}$ yang terdapat di dalam bahan pakan masih tinggi bila dibandingkan dengan kebutuhan P oleh ikan. Menurut Watanabe (1988), jumlah P di dalam pakan bervariasi disesuaikan dengan kebutuhan ikan yang dibudidayakan, ikan mas dan nila membutuhkan $\mathrm{P}$ di dalam pakan masing-masing 0,6\%-0,7\% dan 0,8\%-1,0\%. Namun dibandingkan dengan hasil penelitian sebelumnya Sukadi (2010) total P pakan di Waduk Cirata antara 1,38\%-5,18\%. Dengan demikian sudah ada penurunan total P pakan tapi penurunannya belum sesuai dengan total $\mathrm{P}$ pakan ikan yang umum dibutuhkan oleh ikan.

Mengacu pada Tabel 3 terlihat bahwa rata-rata ikan membutuhkan P di dalam pakan kecil dari 1\%. Sementara pakan yang terdapat di Waduk Cirata P pakan yang paling rendah 1,22\%. Berpedoman pada jumlah $\mathrm{P}$ dalam pakan yang beredar saat ini maka $\mathrm{P}$ dalam pakan masih harus diturunkan lagi disesuaikan dengan kebutuhan P pakan yang dibutuhkan oleh ikan. (berpontensi meningkatkan limbah P dari sisa pakan yang tidak termanfaatkan oleh ikan karena di samping pakan yang tidak termakan oleh ikan akibat pemberian pakan yang berlebihan juga kandungan P pakan melebihi kebutuhan ikan).

Mutu pakan yang beredar di Waduk Cirata umumnya belum memenuhi standar nutrisi pakan. Kandungan protein pakan yang masih rendah, sebaliknya kandungan P pakan yang masih di atas kebutuhan standar kebutuahan $\mathrm{P}$ oleh ikan pada umumnya. Kondisi mutu pakan yang demikian terus akan memicu meningkatnya sisa pakan yang akan terbuang karena pakan yang diberikan tidak dapat dicerna dengan baik oleh ikan. Hal ini tidak hanya merugikan pembudidaya namun yang lebih buruk akan berimplikasi terhadap kerusakan lingkungan akibat beban limbah dari sisa pakan. Guo \& Li (2003) menjelaskan laju pemanfaatan pakan oleh ikan budidaya $14,8 \% \mathrm{~N}$ dan $11,0 \% \mathrm{P}$ pakan. Hampir semua $\mathrm{N}$ dan $\mathrm{P}$ pakan terbuang ke lingkungan perairan. Budidaya ikan patin dengan padat tebar 500 ekor/KJA bobot 1,456 kg dalam luas KJA $110 \mathrm{~m}^{2}$, maka untuk menghasilkan $1 \mathrm{~kg}$ ikan segar membuang beban TN 0,160 kg dan TP 0,035 kg ke lingkungan.

\section{Kebutuhan Pakan Ikan Budidaya}

Jumlah pakan yang dibutuhkan dalam budidaya ikan mas dengan nila satu musim rata-rata $1.205 \mathrm{~kg}$. Sedangkan jumlah pakan yang dibutuhkan dalam satu musim budidaya ikan bawal dangan nila rata-rata $886 \mathrm{~kg}$. Berbedanya jumlah pakan yang dibutuhkan dalam dua pola budidaya tersebut karena adanya perbedaan lama waktu pemeliharaan. Ikan mas dipelihara selama 4 bulan sedangkan ikan bawal hanya 2 bulan.

Pada umumnya pemberian pakan dilakukan antara 3-5 kali dalam satu hari. Pola pemberian pakan menjadi lebih banyak pada saat harga ikan tinggi, karena pembudidaya berupaya mempercepat masa panen, biasanya panen dilakukan setelah pemeliharaan selama 4 bulan dipercepat menjadi 3-3,5 bulan. Cara tersebut dilakukan dengan cara 
Tabel 3. Kebutuhan P dalam pakan ikan dalam persentase bobot pakan

\begin{tabular}{lcc}
\hline \multicolumn{1}{c}{ Jenis ikan } & Kebutuhan $\mathbf{P}(\%)$ & Sumber \\
\hline Anguilla japonica & 0,29 & Arai et al. (1975) \\
Salmo trutta & 0,71 & McCartney (1969) \\
S. Salar & 0,30 & Ketola (1975) \\
Onchorynchus mykiss & $0,70-0,80$ & Ogino \& Tekada (1978) \\
O. keta & $0,50-0,60$ & Watanabe et al. (1980) \\
Cyprinus carpio & $0,60-0,80$ & Ogino \& Tekada (1976) \\
Ictalurus punctatus & $0,45-0,80$ & Lovell (1978) \\
Chrysophrys major & 0,68 & Sakomoto \& Yone (1980) \\
Oreochromis niloticus & 0,90 & Watanabe et al. (1980) \\
\hline
\end{tabular}

Sumber: Beveridge (2004)

ikan diberi pakan sebanyak-banyaknya atau disebut dengan pemberian pakan sistem pompa. Dengan demikian pola pemberian pakan yang dikembangkan oleh pembudidaya tidak sesuai dengan teknologi pemberian pakan dalam sistem budidaya ikan sesuai petunjuk teknis. Schmittou (1991) menjelaskan bahwa pemberian pakan sebaiknya dilakukan tiga kali setiap hari sebanyak 3\% dari bobot badannya; pemberian dosis pakan yang baik antra $3 \%-5 \%$ dari total biomassa tubuh ikan per hari (Sukadi et al., 2007).

Pemberian pakan yang tidak mengikuti teknologi pemberian pakan, maka jumlah dan dosis pakan yang diberikan menjadi tidak sesuai dengan kebutuhan ikan. Pemberian pakan secara berlebihan mengakibatkan pakan yang dimakan oleh ikan tidak dapat dicerna dengan baik dan tidak semua pakan dapat dikonsumsi oleh ikan. Teknik pemberian pakan yang demikian juga dapat meningkatkan jumlah sisa pakan yang terbuang ke perairan. Krismono \& Wahyudi (2001) menjelaskan pemberian pakan dengan sistem pompa jumlah pakan yang terbuang berkisar antara 20\%-30\% ke lingkungan perairan.

\section{Keragaan Produksi Ikan}

Produksi ikan yang dibudidaya di Waduk Cirata untuk setiap penebaran benih sebanyak $284 \mathrm{~kg}$ ikan mas dan $138 \mathrm{~kg}$ ikan nila dalam waktu selama 4 siklus mas dan 2 siklus nila dalam setahun dibutuhkan pakan sebanyak 4,57 ton/ petak/tahun dengan produksi 2,7 ton/petak/tahun (Tabel 4). Sedangkan untuk budidaya ikan bawal dan nila, penebaran benih $610 \mathrm{~kg}$ mas dan $122 \mathrm{~kg}$ nila dibutuhkan
Tabel 4. Produksi ikan per petak KJA dalam satu tahun

\begin{tabular}{|c|c|c|c|}
\hline Pola budidaya & $\begin{array}{c}\text { Pakan } \\
\text { (ton) }\end{array}$ & $\begin{array}{l}\text { Produksi } \\
\text { (ton) }\end{array}$ & $\begin{array}{l}\text { Konversi } \\
\text { pakan }\end{array}$ \\
\hline Ikan mas & 4,57 & 2,41 & 1,69 \\
\hline Ikan nila & & 0,29 & \\
\hline Ikan bawal & 4,61 & 3,23 & 1,33 \\
\hline Ikan nila & & 0,23 & \\
\hline Total & 9,18 & 6,16 & 3,02 \\
\hline Rataan & 4,59 & 1,54 & 1,51 \\
\hline
\end{tabular}

pakan sebanyak 4,61 ton/petak/tahun dengan produksi 3,46 ton/petak/tahun dalam waktu 5 siklus budidaya bawal dan 2 siklus nila dalam setahun.

Produksi ikan mas per petak KJA, bila dibandingkan dengan kondisi produksi ikan pada tahun 1995 pada saat kondisi air waduk masih bagus satu petak KJA produksi sekitar $2.300 \mathrm{~kg} / \mathrm{siklus}$ (Abery et al., 2005), sementara sekarang produksi hanya $604 \mathrm{~kg} /$ siklus. Perbedaan produktivitas ikan di Waduk Cirata yang sangat signifikan tersebut diduga akibat kondisi air waduk saat ini sudah buruk untuk budidaya, di samping itu, juga terjadinya penurunan kualitas pakan.

\section{Beban Sisa Pakan dalam Budidaya Ikan}

Hasil perhitungan beban P dari sisa pakan, satu petak KJA beban $P$ yang terbuang ke lingkungan besarnya 0,02 ton/tahun atau sebanyak $23 \mathrm{~kg} /$ petak KJA/tahun (Tabel 5). Berdasarkan data jumlah KJA terakhir sebanyak 49,985 
Tabel 5. Beban P dari sisa pakan budidaya ikan per petak/tahun di Waduk Cirata

\begin{tabular}{lcccccc}
\hline \multicolumn{1}{c}{$\begin{array}{c}\text { Pola } \\
\text { budidaya }\end{array}$} & $\begin{array}{c}\text { Jumlah } \\
\text { pakan }\end{array}$ & Produksi & $\begin{array}{c}\text { P } \\
\text { pakan/ton }\end{array}$ & $\begin{array}{c}\text { Jumlah P } \\
\text { pakan }\end{array}$ & Jumlah P & Beban P \\
\hline Ikan mas dan nila & 4,57 & 2,70 & 0,02 & 0,07 & 0,04 & 0,03 \\
Ikan bawal dan nila & 4,61 & 3,46 & 0,01 & 0,07 & 0,05 & 0,02 \\
\hline Total & 9,18 & 6,16 & 0,03 & 0,14 & 0,09 & 0,05 \\
\hline Rataan & 4,59 & 3,08 & 0,01 & 0,07 & 0,05 & 0,02 \\
\hline
\end{tabular}

petak yang tidak beroperasi sebanyak 10\%, jadi jumlah KJA yang aktif sebanyak 44,987 petak KJA (Anonim, 2008b). Dengan demikian jumlah total beban $\mathrm{P}$ dari sisa pakan yang terbuang ke Waduk Cirata sebanyak 900 ton dalam waktu satu tahun. Menurut Guo \& Li (2003), menyatakan lebih dari 85\% N dan P dari pakan yang terbuang di daerah sekeliling KJA.

Jumlah beban $\mathrm{P}$ yang terbuang ke perairan waduk dari sisa pakan budidaya ikan dalam KJA masih tinggi. Hal ini terjadi diduga akibat dari berbagai hal yaitu kualitas perairan waduk sudah menurun, kualitas pakan kurang bagus, jumlah KJA melebihi daya dukung, dan penerapan teknologi tidak sesuai petunjuk teknis.

Sukadi et al. (2007) menjelaskan beberapa kriteria penggunaan pakan yang harus diperhatikan dalam pemberian pakan yaitu gunakan pakan dengan kandungan $P$ yang minimal (0,6\%-0,9\%); pakan yang menghasilkan nilai FCR yang rendah, berikan pakan sebanyak 3\%-5\% bobot biomassa tubuh ikan per hari, kurangi frekuensi pemberian pakan saat nafsu makan ikan berkurang, pada perairan yang mesotrofik pemberian pakan sebanyak $8 \mathrm{~kg} / \mathrm{hari} / \mathrm{luas}$ dan minimalkan limbah akibat pakan pada saat disimpan sampai pakan diberikan.

\section{KESIMPULAN}

Aktivitas budidaya ikan sistem KJA yang dikelola secara intensif memberikan beban sisa pakan yang cukup besar terhadap lingkungan perairan waduk. Satu petak KJA menghasilkan $23 \mathrm{~kg}$ beban $\mathrm{P}$ per tahun dan dalam setahun jumlah KJA yang beroperasi 44.987 petak KJA yang menghasilkan 900 ton beban P yang terbuang ke perairan waduk. Budidaya sistem KJA yang dibutuhkan dalam meminimalisasi sisa pakan: meningkatkan pembinaan terhadap pembudidaya tentang manajemen pakan, mengontrol kualitas pakan secara berkala, serta menggunakan benih unggul atau mencari komoditas yang sesuai dengan kondisi lingkungan perairan waduk.

\section{DAFTAR ACUAN}

Abery, N.W., Sukadi, F., Budhiman, A.A., Kartamihardja, E.S., Koeshendrajana, S., \& De Silva, S.S. 2005. Fisheries and cage culture of three reservoir in West Java, Indonesia; A case study of ambitious development and resulting interactions. Fisheries Management and Ecology, 12(5): 315-330.

Anonim. 2008a. Pedoman pengelolaan ekosistem danau. Kementerian Lingkungan Hidup. Jakarta, 118 hlm.

Anonim. 2008b. Kegiatan kajian perhitungan daya tampung sungai 3 DAS dan 4 waduk prioritas. Badan Pengelolaan Lingkungan Hidup Daerah Provinsi Jawa Barat. Bandung, $127 \mathrm{hlm}$.

Anonim. 2009. Undang-Undang Republik Indonesia Nomor 32 tentang Perlindungan dan Pengelolaan Lingkungan Hidup. $110 \mathrm{hlm}$.

Beveridge, M.C.M. 2004. Cage aquaculture. Edisi ke-3. India: Replika Press Pvt Ltd. 368 pp.

Guo, L.G. \& Li, Z.J. 2003. Effect of nitrigen and phosphorus from fish cage culture on the communities of a shallow lake in middle Yangtze River basin of China. Aquaculture, 226: 202-212.

Krismono \& Wahyudi, N.A. 2001. Analisis kebijakan pengelolaan keramba jaring apung sebagai salah satu kegiatan pengelolaan danau dan waduk. Dalam Analisis Kebijakan Pembangunan Perikanan. Pusat Riset Pengolahan Produk dan Sosial Ekonomi, Badan Riset Kelautan dan Perikanan, Departemen Kelautan dan Perikanan. Jakarta, hlm. 75-85. 
Sukadi, M.F., Kartamihardja, E.S., Koeshendrajana, S., Maskur, Sukimin, S., Rina, Sasongko, A., Murtiati, Priyatna, F.N., Jumhana, D., \& Umar, C. 2007. Panduan teknis pengelolaan perikanan secara bersama pada perairan waduk di Indonesia. Departemen Kelautan dan Perikanan Kerja sama dengan Australian Centre for International Agricultural Research. 55 pp.

Sukadi, M.F. 2010. Ketahanan dalam air dan pelepasan nitrogen dan fosfor ke air media dari berbagai pakan ikan air tawar. J. Ris. Akuakultur, 5(1): 1-12.
Schmittou, H.R. 1991. Cage culture. A method of fish production in Indonesia. Central Research Institute for Fisheries. Jakarta, 114 pp.

Watanabe, T. 1988. Fish nutrition and mariculture. JICA texbook. The General Aquaculture Course. Departement of Aquatic Biosciences. Tokyo University of Fisheries. 233 pp. 
